Оскільки учні ще не вивчали змінного струму та принцип роботи трансформатора, ми вважаємо недоцільним вивчення будови різноманітних випрямлячів, а звернути лише їх увагу на використання діодів у випрямлячах.

Висновки. Запропонована методика вивчення електротехнічних робіт учнями 7-9 класів передбачає як традиційні підходи до вивчення навчального матеріалу, так і нові. Головною відмінністю $є$ те, що матеріал вивчається без використання фундаментальних фізичних знань учнів 3 основ наук, які вивчаються у школі. Спираючись на життєвий досвід учнів та методичні розробки, з'являється можливість вивчення вказаного матеріалу учнями, яка повною мірою задовольняє усі вимоги щодо вивчення електротехнічних робіт.

\title{
Література
}

1. Тхоржевський Д.О. Методика трудового i професійного навчання та викладання загально технічних дисциплін: [навч. посіб.]. - 3-є вид., перероб. і допов.] / Д.О. Тхоржевський. - К.: Вища шк., 1992. - 334 с.

2. Навчальна програма «Трудове навчання. 5-9 класи» / за загальною редакцією В.М. Мадзігона. - К.: Вища школа, 2001. - 178 с.

3. Терещук Б.М. Трудове навчання. Техн. види праці: [підруч. для 8 кл. загальноосвіт. навч. закладів] / Б.М. Терещук. - К.: «Видавництво «Арка», 2005. - 208 с.

Стаття надійшла до редакції 12.05.2012 p.

УДК: 372.4.035.3.

О. Д. Літковець, ст. викладач, Рівненський державний гуманітарний університет

\section{ДОСЛІДЖЕННЯ МІЖПРЕДМЕТНИХ ЗВ'ЯЗКІВ У ФОРМУВАННІ ГРАФІЧНИХ УМІНЬ В УЧНІВ ПОЧАТКОВИХ КЛАСІВ}

Літковець О.Д. Дослідження міжпредметних зв'язків у формуванні графічних умінь в учнів початкових класів.

Статтю присвячено дослідженню міжпредметних зв 'язків у формуванні графічних умінь в учнів початкових класів.

Ключові слова: графічні уміння, міжпредметні зв'язки, графічна діяльність.

Литковеи Е.Д. Исследования межпредметных связей в формировании графических умений у учеников начальных классов.

Статья посвящена исследованию межпредметных связей в формировании графических умений в учеников начальных классов.

Ключевые слова: графические умения, межпредметные связки, графическая деятельность

Litkovets E. Studies of interdisciplinary relationships in the formation of graphic skills to primary school students.

The article is sanctified to research of intersubject connections in forming of graphic abilities for the students of initial classes.

Key words: graphic abilities, intersubject copulas, graphic activity.

Актуальність та постановка проблеми. Проблема міжпредметних зв’язків є однією із найважливіших у педагогіці, що зумовлено насамперед сучасними процесами інтеграції та диференціації наукових i технічних галузей діяльності людини. 
Міжпредметні зв'язки шкільних дисциплін математика, образотворче мистецтво та трудове навчання у початковій ланці за своєю суттю $€$ головними чинниками у формуванні графічних умінь в учнів початкових класів. Послідовна, систематична реалізація іх у педагогічному процесі значно посилює його загальну ефективність, а також позитивно впливає на формування різнобічного розвитку учня.

Оскільки саме початкова школа $\epsilon$ пропедевтичною ланкою, де закладається фундамент навчальної діяльності, значною мірою має забезпечуватися подальший розвиток та успішне засвоєння навчального матеріалу, в основі якого лежить реалізація міжпредметних зв'язків. Формування графічних умінь в учнів $є$ метою графічної пропедевтики в початкових класах. Тобто на уроках математики, образотворчого мистецтва та трудового навчання потрібно формувати уміння аналізувати, читати, зображати, будувати тощо графічні об'єкти. Проте ця мета не реалізується в повному обсязі через недостатню реалізацію міжпредметних зв'язків.

Аналіз останніх досліджень і публікацій. Теоретичні основи цієї проблеми знайшли відображення у працях відомих зарубіжних та вітчизняних психологів, дидактів, методистів. Важливим чинником розвитку особистості учня, як одного з основних компонентів структури навчальної діяльності учнів, уміння розглядалися в роботах В. Давидова, Д. Ельконіна, Г. Люблінської, А. Маркової, В. Рєпкіна та інших.

Теоретичні основи графічних умінь в учнів розкрито в роботах зарубіжних науковців А. Ботвіннікова, О. Галкіна, Л. Гурова, Т. Данюшевської, А. Павлової, В. Зикової, Є. Кабанової-Меллер, Т. Кудрявцева， В. Куріної, Н. Лінькової, Б. Ломова, Г. Рубіної, Н. Четверухіна, І. Якиманської та інших. В Україні проблеми графічної підготовки школярів розглядали В. Буринський, А. Верхола， А. Гедзик， О. Джеджула， М. Козяр， В. Моштук， В. Науменко, Г. Райковська, В. Сидоренко, Д. Тхоржевський, Ю. Фещук, В. Чепок, 3. Шаповал, Н. Щетина, М. Юсупова та ряд інших дослідників.

Важливою умовою підвищення якості знань і умінь $є$ послідовна реалізація міжпредметних зв'язків у навчанні. Численні дослідження з даної проблеми (Н. Антонов, П. Атутов, А. Бейсенбаєва, П. Кулагін, В. Федорова та інші) розкривають сутність, функції та значення міжпредметних зв'язків, шляхи їх реалізації. Однак у цих дослідженнях в основному акцентується на вивчення предметів теорій, закономірностей, принципів, застосування знань 3 різних предметів у процесі розв'язання міжпредметних завдань. Незначна кількість робіт (Г. Вергелес, Н. Дружиніна, Т. Рамзаєва, С. Тадіян та інші) присвячена дослідженню міжпредметних зв'язків у початковій ланці освіти.

Об'єктивні можливості для формування графічних умінь в учнів закладені в змісті навчальних предметів (математика, образотворче мистецтво, трудове навчання), які в подальшому повинні сприяти їх вдосконаленню в середніх та старших класах. На жаль, цей важливий, але поки що невикористаний резерв підвищення ефективності навчального процесу далеко не завжди і не повною мірою використовуються в навчанні молодших школярів. 
Мета статті полягає в дослідженні міжпредметних зв'язків навчальних дисциплін (математика, образотворче мистецтво та трудове навчання) у формуванні графічних умінь в учнів на основі аналізу змісту графічної діяльності.

Виклад основного матеріалу. Важливим засобом у формуванні графічних умінь в учнів є міжпредметні зв'язки.

Міжпредметні зв'язки - це провідний дидактичний інструмент інтеграції. Модель міжпредметних зв'язків $є$ структурованою і має такі складники: зміст, обсяг, спосіб зв'язків. Здійснюючи інтеграцію через міжпредметні зв'язки, треба знайти смислові відповідності елементів змісту навчального матеріалу, що належить двом чи більше дисциплінам, спланувати комплексне використання умінь під час розв'язання навчальних завдань, поєднаних інформацію так, щоб її визначала багатогранна єдність [2].

Навчальна діяльність учня складається із сприймання, розуміння й відтворення наукових теорій, розв'язання пізнавальних задач, проведення експериментів, дослідів, виконання практичних робіт, творчої діяльності під час трудового навчання. Міжпредметні зв'язки часто визначають через міжпредметні відношення, що виявляються через зв'язок явищ і процесів, закономірності виокремлення окремих дисциплін. Відбувається глибоке проникнення у процеси вивчення, комплексний розгляд об'єктів, явищ. Ці кореляції стають зв'язками лише тоді, коли їхні елементи стануть динамічними щодо змін у послідовності елементів навчальних дисциплін, у змісті знань та умінь, у видах діяльності вчителя й учня та будуть сприяти утворенню міжпредметної структури навчальних умінь [5].

Процес засвоєння та застосування графічних умінь має бути безперервним і взаємопов'язаним з іншими навчальними дисциплінами. Це $\epsilon$, на нашу думку, головною умовою формування графічного компонента у процесі графічної діяльності.

Графічна діяльність учнів на уроках трудового навчання має широкі можливості для їхнього розумового розвитку. Проаналізовані у процесі досліджень механізми навчально-пізнавальної діяльності дають підстави стверджувати, що «будь-яка графічна дія спочатку здійснюється подумки, на основі чого в учня створюється певний графічний образ, а потім він утілюється у реальних графічних побудовах» [1, с.32]. Непомітна зовні розумова діяльність становить тісну взаємодію мислительних операцій, образного мислення і пам'яті. У результаті цього і «утворюється графічний образ предмета, який фіксує в уяві учня його властивості, що умовно відображені на кресленні або підлягають відображенню шляхом побудови необхідних зображень» [3, с.19].

У своєму дослідженні графічну діяльність ми розглядаємо як цілісний багатогранний процес, який становить взаємодію розумових та практичних дій, спрямованих на створення уявлень про просторові властивості предметів та їх умовне відображення на площині або відтворення цих просторових властивостей в уяві на основі наявних умовних зображень. 
Як вже зазначалось, формування графічних умінь в учнів початкових класів має спільні проблеми в процесі вивчення таких предметів: математика, образотворче мистецтво, трудове навчання: технічна і художня праця. Тому проаналізуємо дані навчальні програми початкової школи задля визначення тем графічного змісту при вивченні яких в учнів формуються графічні уміння [4].

Зміст графічної діяльності з математики:

I клас. Геометричні фігури: круг, трикутник, чотирикутник, п’ятикутник. Пряма і непряма лінії. Точка і пряма. Належність точки прямій. ïx зображення. Видозміна фігур. Довжина відрізка. Одиниці довжини: см, дм. Побудова відрізків заданої довжини. Побудова трикутника i чотирикутника за точками в зошиті у клітинку. Побудова відрізка на $a$ см довшого чи коротшого від даного.

II клас. Розпізнавання відомих фігур, які входять у склад інших Ламана лінія. Довжина ламаної. Замкнена й незамкнута ламана лінія. Класифікація многокутників у залежності від кількості кутів. Поняття периметра чотирикутника. Кут. Елементи трикутника. Прямий кут. Розпізнавання прямого кута 3 допомогою еталона. Самостійне виготовлення еталона прямого кута. Прямокутник. Довжина і ширина прямокутника. Квадрат. Побудова квадрата у зошиті в клітинку. Вертикальні й горизонтальні прямі лінії. Побудова прямокутника і квадрата за відомими сторонами у зошиті в клітинку. Коло. Круг. Радіус кола. Побудова кола заданим радіусом.

III клас. Латинський алфавіт. Позначення геометричних фігур великими буквами латинського алфавіту. Побудова квадрата за відомим периметром. Введення частин і використання при цьому геометричних фігур. Поділ фігур на частини способом перегинання. Взаємне розміщення прямої, точок і відомих геометричних фігур. Міри довжини: метр, дециметр, сантиметр, міліметр. Побудова прямого кута за клітинками. Побудова трикутника і прямокутника за зразком /у зошиті/. Побудова й видозміна фігур. Послідовне відкладення відрізків різної довжини на прямій. Кратне порівняння довжини відрізків.

IV клас. Площа фігури. Порівняння площ. Визначення площ ступінчатих фігур, які поділені на одиничні квадрати. Одиниці вимірювання площі: квадратний сантиметр, квадратний дециметр. Визначення площі прямокутника. Наближене визначення площ інших фігур. Палетка. Видозміна фігури, визначення іiі площі та площі іiі частин. Поділ геометричних фігур на різні частини способом перегинання. Масштаб.

Образотворче мистецтво ставиться у навчальному плані школи як один 3 предметів художнього виховання дітей. 3 цих позицій ссформовано i програму предмета. Не заперечуючи жодною мірою важливості цієї задачі, можна, однак, знайти в образотворчому мистецтві багато елементів, що мають істотне значення з формування графічних умінь в учнів.

Зміст графічної діяльності з образотворчого мистецтва [4]. 
I клас. Види ліній та їх напрямків. Графічні навички, координація рухів. Виражальні можливості ліній. Подібність форм та розмірів. Елементарні пропорції. Взаємозв'язок основної форми і частин. Цілісність форми. Заповнення площини аркуша. Виражальні можливості силуетної форми. Зіставлення силуетних форм будинків. Виражальні можливості силуетних геометричних форм. Усвідомлення виробу положення аркуша паперу (горизонтальне чи вертикальне). Заповнення всієї зображувальної поверхні. Порівняльний характер форм та розмірів, їх складових частин (елементів).

II клас. Виражальні можливості силуетної форми. Порівняльний аналіз форм, розмірів та пропорцій. Способи передавання просторового явища загороджування при розташуванні силуетів архітектурних споруд на площині. Виражальні можливості об'ємної форми. Передавання характеру загальної (силуетної) форми через розроблення фрагмента. Передавання фактури (лінією, штрихом, крапками, плямою та їх сполученнями). Свідомий вибір типів ліній та їх напрямків при створенні певного образу. Передавання форми та декору предметів і об'єктів графічними засобами. Рівномірне заповнення площини аркуша.

III клас. Сприймання: засоби виразності у графіці. Специфіка роботи художника-графіка, матеріали та інструменти, техніки, обладнання. Засоби передачі руху у природі. Створення асоціативної композиції графічними засобами виразності, можливо - у поєднанні з кольором. Лінія як засіб виразності. Передавання будови та форми, фактури і текстури графічними засобами. Пляма як засіб виразності. Силует. Виразність силуетної форми (тварин, комах, птахів). Створення орнаментальної композиції у фризі.

IV клас. Сприймання: передавання основних особливостей будови i характеру руху тварин. Пластична виразність силуетної форми, iii декоративна насиченість, художньо-образна характеристика. Основні пропорції та особливості будови людини, передавання руху людини, пластичної виразності силуетної та об'ємної форми. Початкове освоєння прийомів петриківського розпису. Принципи, прийоми та засоби організації композиції: свідомий вибір елементів композиції і формату аркуша; підпорядкованість форми та розміру елементів композиції формату; розуміння (та свідомий вибір) симетричного або асиметричного принципу композиційної організації площини; ритм у композиції; визначення композиційного центру (кольором, тоном, розміром, фактурою тощо); навички вільного писання шрифту (пензлем, пальцем, фломастером тощо).

Графічна діяльність на уроках трудового навчання $\epsilon$ передумовою створення образів, які відображають просторові властивості і відношення предметів [4, с.62]. Програмою передбачено змістове забезпечення графічної діяльності, в процесі якої відбувається формування графічних умінь в учнів.

Зміст графічної діяльності з трудового навчання: технічна і художня праця [4].

I клас. Основні сфери життєдіяльності людини: природа, інші люди, інформаційні знаки, техніка, художні образи. Зображення на площині: 
космічний пейзаж у рамці витинанці. Колірно-графічні вправи з використанням кругів, овалів, дугоподібних ліній («ліній вихору», «ліній хвиль», «чарівних завитків»). Види ліній в орнаментах: хвиляста, зигзагоподібна (ламана). Заповнення площини аркуша паперу. Розмічання за допомогою шаблона або трафарету. Виражальні можливості силуетної форми. Передавання характеру об'ємної форми. Передача форм та розмірів, їх порівняльний аналіз. Зображення фігури людини: контур, силует, костюм. Конструювання i моделювання іграшкового одягу. Симетрія як засіб гармонізації форми (на елементарному рівні). Розмічання за допомогою шаблонів і трафаретів новорічних іграшок. Дивосвіт інформаційних знаків у довкіллі: рекламне «україноцвіття». Виражальні можливості ліній. Види ліній i напрямків. Подібність форм. Зображення форм і декору писанки.

II клас. Засоби виразності в різних видах мистецтва. Замальовування різних фрагментів 3 різних видів мистецтв. Площини-основи у макеті діорамної композиції. Зображення неба на площині: передача загальних форм предметів за їх характерними ознаками, контуром і прилеглим простором. Передача форми предметів довкілля графічними засобами. Будова дерева (форма як конструкція). Елементарні уявлення про симетричну форму. Значення осі симетрії для побудови зображення. Навички малювання птахів та створення декоративного художнього образу. Будова птахів. Виражальні можливості об'ємної декоративної форми. Виражальні можливості силуетної форми тварин. Зображення фігури людини та іiі одягу. Розвиток емоційноестетичного сприймання i передача характерних особливостей силуету людини. Виражальні можливості силуетної форми. Порівняльний аналіз форм, розмірів та пропорцій. Засоби виразності мистецтв. Замальовування об'єктів, елементів декору. Культура українського національного побуду у творах пластичних мистецтв. Узгодження декоративного оздоблення 3 формою. Освоєння просторових явищ. Передача просторового явища. Виражальні можливості об'ємної форми. Поглиблене ознайомлення 3 професіями типу «людина - художні знаки інформації». Знаки візуальної інформації у рекламному і поліграфічному мистецтвах. Навички зображення казково-символічних птахів. Ознайомлення 3 народними традиціями писанкарства. Узгодження і контраст силуетних форм і декору. Композиційне заповнення малюнком зображувальної поверхні.

III клас. Масштаб як одна з композиційних закономірностей. Розроблення різних форм істот на основі сузір'їв (графічно і в кольорі). Пропорції рослинних форм як засоби композиційної виразності. Графічне образотворення рослинних форм на основі літер, крапель, сонцезайчиків. Пропорції і пластика живих істот. Способи передачі пропорцій форми і пластичної виразності істот на площині та у просторі. Графічне образотворення з опорою на контури літер, крапель, хвиль, кругів, а також уяви. Пропорції і пластика людського тіла. Передача пластичної виразності руху людини і пропорцій іï тіла художніми засобами. Текстильний дизайн: конструювання і моделювання костюмних макетів за аналогами форм довкілля. Символіка храмового свята у місцевому 
населеному пункті. Симетрія як засіб композиційної виразності у дитячому декоративно-вжитковому мистецтві. Ескізні замальовки декоративного посуду, оздоблювальних швів і орнаментів. Динаміка і статика як засоби композиційної виразності у дитячому мистецтві промислового дизайну (технічному i художньому конструюванні). Професії рекламіста, комп'ютерного графіка, графічного дизайнера або інших споріднених видів діяльності.

IV клас. Масштаб як один із засобів композиційної виразності (розширено, поглиблено). Графічні композиції і конструювання на основі геометричних фігур. Символіка рослин. Стилізація рослинних форм кольоро-графічними засобами. Стилізація природних та живих форм істот графічними засобами. Конструктивні і художні особливості українського національного костюма та українських народних іграшок. Стилізація форми ялинки, символіка іiі прикрас. Ритм як засіб композиційної виразності у дитячих творах декоративно-ужиткового мистецтва (основні елементи петриківського розпису). Елементи художньої картографії художнього краєзнавства (з використанням контрасту і нюансів).

Отже, проаналізувавши навчальні програми 1-4 класів: «Математика», «Образотворче мистецтво» та «Трудове навчання: технічна і художня праця», ми дослідили міжпредметні зв'язки з формування графічних умінь.

Теоретичний та методичний аналіз змісту програм надає змогу виокремити основні графічні уміння, якими має володіти учень: складати план-схему виготовлення виробу; розробляти ескіз декоративної композиції; уміння передавати образну виразність предмета, підкреслювати ідею задуму допоміжними елементами; узагальнювати і переробляти реальні мотиви у декоративні; узагальнювати образ, виражати асоціативність, стильову єдність; взаємопов'язувати матеріал, форму і декорування виробів, їх залежність від призначення; передавати характерні особливості форми, пропорції, розміру предметів, взаєморозміщення і взаємозв'язок частин; ураховувати зв'язок між призначенням і характером конструкції виробу; розробляти та будувати конструкцію виробу; читати графічне зображення та ін.

Також, із розглянутого матеріалу стає очевидним, що графічна підготовка учнів на різних уроках у початковій школі не забезпечує ні системності у цій роботі, ні необхідного обсягу графічних умінь. Тому основне навантаження у розв'язанні цього питання покладено на уроки трудового навчання, які є системостворюючими у графічній підготовці учнів, де забезпечуються міжпредметні зв'язки в цьому питанні.

Зокрема у першому класі визначальними є уроки математики, де учні розпізнають геометричні фігури та вимірюють і будують за допомогою лінійки відрізки. На уроках трудового навчання вони оволодівають прийомами розмітки за шаблоном прямокутних форм, а на образотворчому мистецтві порівнюють і визначають спільні та відмінні ознаки предметів. Причому уроки математики закладають основу роботи у другому класі 3 трудового навчання. 
На уроках трудового навчання другокласники поглиблюють уміння розпізнавати і порівнювати геометричні фігури, розмічати на папері та виготовляти їх. Уроки образотворчого мистецтва на цій основі розвивають спостережливість, забезпечують можливість аналізу форми, пропорцій, взаєморозташування та взаємозв'язку предметів і їх частин. Математика другого класу створює підгрунтя для графічної роботи учнів у наступному класі і по суті випереджає на інформаційному рівні інші предмети, що потрапили в поле зору нашого дослідження.

Графічна діяльність учнів третього класу на уроках трудового навчання базується на основі одержаних з математики у другому класу знань i певного досвіду, що забезпечує можливість побудови розгорток геометричних фігур. $€$ й одна цікава деталь: на уроках трудового навчання у третьому класі учні засвоюють прийоми побудови кола, а на уроках математики це вони роблять у наступному - четвертому класі. Уроки образотворчого мистецтва дозволяють співвідносити зображення 3 природними предметами.

У четвертому класі забезпечується поетапна робота на різних уроках 3 послідовності побудови зображення пласкої деталі, а на малюванні відпрацьовуються елементарні правила зображення об'ємних предметів.

Розглянуті факти дозволяють зробити узагальнення про те, що багато важливих графічних умінь розвиваються відокремлено на різних уроках, що не сприяє їх поглибленню та закріпленню, а такий підхід у навчанні не забезпечує озброєння міцними знаннями та сформованими практичними уміннями. Звичайно, це $\epsilon$ причиною слабкої підготовки до формування графічних умінь учнів на відповідних уроках у середніх та старших класах, оскільки основа їх закладається в початкових класах.

Висновки. На грунті аналізу нині чинних програм для початкової школи з математики, образотворчого мистецтва, трудове навчання: технічна і художня праця ми констатували, що графічний матеріал із зазначених предметів вивчається без забезпечення міжпредметних зв'язків. Як показують результати проведеної роботи, лише 6,37\% завдань від загальної кількості у підручниках 3 математики містять графічний матеріал і тільки 4,92\% - передбачають застосування графічних умінь на практиці. При цьому зауважується, що навіть ця кількість використовується здебільшого як допоміжний засіб.

Подібну картину спостерігаємо і на уроках образотворчого мистецтва де майже повністю не реалізуються можливості «технічного малювання» і формування графічних умінь в учнів, нині чинна програма 3 трудового навчання у порівнянні 3 попередніми не містить низки важливих для графічної підготовки тем.

Розглянуті факти доводять думку про те, що багато важливих графічних умінь розвиваються відокремлено на різних уроках, а це не сприяє їх поглибленню та закріпленню. Такий підхід у навчанні не забезпечує озброєння учнів початкових класів міцними знаннями та сформованими практичними уміннями. 
Перспективи подальших досліджень полягають в розробленні моделі формування графічних умінь в учнів початкових класів на уроках трудового навчання.

\title{
Лiтература
}

1. Андрианов П.Н. Развитие технического творчества в трудовом обучении учащихся общеобразовательной школы / П.Н. Андрианов. - М., 1985. - 131 с.

2. Гриценко Н. Інтеграція предметів природничо-математичного циклу в умовах профільного навчання / Н. Гриценко // Завуч. - 2007. - №21 (липень). - С. 25-27.

3. Долбилин Н.П. О курсе наглядной геометрии в младших классах / Н.П. Долбилин, Н.Ф.Шарыгин // Математика в школе. - 1990. - №6. - С. 19-21.

4. Програма для середньої загальноосвітньої школи 1-4 класи. - К. : Початкова школа, 2006. $-432 \mathrm{c}$.

5. Сергієнко В. Науково-практичне місце інтеграції та інтеграційні особливості навчального процесу в ліцеї економічного профілю / В. Сергієнко // Завуч. - 2007. - №21 (липень). - С. 6-7.

Стаття надійшла до редакції 25.05.2012 p.

УДК $373.5: 37$

\author{
A.I. Терещук, \\ докторант, \\ Уманський ДПУ \\ імені Павла Тичини
}

\section{ПРОБЛЕМИ ПРОФЕСІЙНОЇ ОРІЄНТАЦІЇ ТА САМОВИЗНАЧЕННЯ УЧНІВ СТАРШОЇ ШКОЛИ}

Терешук А. І. Проблеми професійної орієнтації та самовизначення учнів старшої школи.

У статті розглянуто проблеми професійної орієнтаиї учнів та професійного самовизначення старшокласників, проаналізовано особливості традиційної системи профорієнтації у зв'язку з пошуком нових шляхів розв'язку проблеми.

Ключові слова: професійна орієнтація, самовизначення, соиіальне замовлення, індивідуальні потреби особистості, діяльнісний підхід.

Терещук А. И. Проблемь профессиональной ориентащии и самоопределения учащихся старшей школь.

В статье рассмотрены проблемы профессиональной ориентации учашихся $и$ профессионального самоопределения старшеклассников, проанализированы особенности традиционной системы профориентации в связи с поиском новых способов решения проблемы.

Ключевые слова: профессиональная ориентация, самоопределение, сочиальный заказ, индивидуальные потребности личности, деятельный подход.

Tereshuk A. I. Problems professionally orientation and self high school students.

The problems of professional orientation of students and professional self seniors, analyzes the features of the traditional system of vocational guidance in the search for new ways of solving problems.

Key words: professional orientation, self-determination, social order, the individual needs of the individual, active approach.

Постановка проблеми. Загальним теоретичним проблемам формування готовності до професійного самовизначення у майбутній трудовій діяльності присвячено ряд досліджень К. Абульханової-Славської, Ю. Алферова, С. Батишева, Л. Буєвої, Ф. Іващенка, С. Клімова, Г. Костюка, В. Моляко, В. Полякова, М. Скаткіна, В. Чебишевої та інших. 